\title{
Auxiliary choice with Dutch verbs of directed motion
}

\author{
Maaike Beliën \\ Delft University of Technology
}

Dutch perfect tenses are constructed with the auxiliaries zijn 'be' and hebben 'have'. Over the years, several semantic generalizations have been proposed to account for this auxiliary choice. This paper evaluates these generalizations on the basis of examples with verbs of directed motion (draaien 'turn', keren 'turn', and stijgen 'ascend, rise'), collected from the Internet. The paper concludes that these data are problematic for analyses of auxiliary choice in terms of telicity and 'Inferable Eventual Position or State, yet provide support for analyses of auxiliary choice that rely on the notion of 'construal' of the motion event. In particular, the paper argues that $z i j n$ is used when the event is construed as a 'change of state', while hebben is used when it is construed as a 'type of act'.

Keywords: Auxiliary choice, directed motion verbs, semantics, construal, construction grammar, attested data

\section{Introduction}

In the Dutch televised talent show The Voice of Holland and its spin-off, The Voice Kids, the jury members, or 'coaches', are in chairs facing away from the contestants. As they cannot see the contestants, the idea is that they will solely judge the contestants' vocal qualities, and not their looks or performance. To show their approval of a contestant, coaches can press a button that makes their chair turn around, so that they can then see the contestant. For contestants, this is a crucial moment: When a coach turns around for them, they go on to the next round of the competition.

Being such a key element of the show, this turning is much talked about, see, for example, the following comments collected from the Internet: 
(1) Haha, die zus had het niet eens door dat Roel had gedraaid! ${ }^{1}$ haha that sister had it not even through that Roel had turned 'Haha, her sister had not even noticed that Roel had turned!'

(2) Wauw wat een uithaal! Alle coaches hebben gedraaid, wow what a sustained.note all coaches have turned 13 jaar oud en al zoveel talent, dat belooft wat! ${ }^{2}$ 13 year old and already so.much talent that promises something 'Wow, what a high note! All coaches have turned, 13 years old and already so talented, what a promise!'

(3) Jammer dat niemand heeft gedraaid. ${ }^{3}$

'A pity that no one has turned.'

Interestingly, the perfect tenses in these examples are formed with the auxiliary hebben 'have' rather than zijn 'be', which is unexpected in light of some analyses of Dutch auxiliary choice. The examples do, however, sound natural to me and other Dutch speakers whom I have informally consulted. What is more, an exploratory search by means of Google suggests that in the context of these shows, gedraaid 'turned' occurs more often with hebben than with zijn. Entering a few specific strings in the Google search field on 22 February 2013 yielded 12 examples with hebben, three of which are presented in (1)-(3), and only 2 with zijn, see (4) and $(5):^{4}$

(4) Stel: Jij deed een spetterende auditie en iedere coach is gedraaid, [...] suppose: you did a smashing audition and every coach is turned Wie kies je dan als coach?5 who choose you then as coach

'Suppose: Your audition went magnificently and every coach turned. Who do you pick as your coach?'

(5) tenzij er maaréén coach is gedraaid, unless there only one coach is turned dan zit de kandidaat automatisch in dat team ${ }^{6}$ then sits the candidate automatically in that team 'unless only one coach has turned, then the candidate automatically joins that [coach's] team'

On the basis of these and other data with verbs of directed motion, this paper evaluates existing semantic analyses of auxiliary choice in Dutch. Section 2 shows that examples (1)-(3) are problematic for accounts in terms of telicity and 'Inferable Eventual Position or State'. Section 3 argues that the examples instead provide support for analyses that rely on the notion of 'construal' of the motion event. Section 4 
extends the analysis to other verbs that imply a certain direction, i.e. keren, which is a verb of turning too, and stijgen 'rise, ascend'; they are all referred to as 'directed motion verbs' here. ${ }^{7}$ Section 5 briefly reflects on the idea of treating examples such as (1)-(3) as transitives with an unexpressed direct object. Section 6 concludes that the highly specific examples that were gathered from the Internet support the following analysis of auxiliary choice with Dutch verbs of directed motion: Zijn is used when the event is construed as a 'change of state', while hebben is used when it is construed as a 'type of act'.

\section{Analyses in terms of telicity and Inferable Eventual Position or State}

The turning events described in Section 1 are all very similar: They each involve someone making a 180-degree turn while seated in a chair. This section argues that accounts of auxiliary choice in terms of telicity and 'Inferable Eventual Position or State' cannot explain these data, because the events described in (1)-(5) do not differ in these respects: They are all telic, and the subject's eventual position or state can be inferred in each case.

An analysis of auxiliary choice in terms of telicity is presented in van Hout $(1996,2004)$, who states that a telic predicate selects $z i j n$, while an atelic predicate selects hebben (cf. also Zaenen 1993 and Sorace 2000). To determine whether a predicate is telic or atelic, van Hout uses temporal modifiers as diagnostics (cf. Dowty 1979): Atelic predicates combine with 'durative modifiers', such as urenlang 'for hours', while telic predicates combine with 'frame adverbials', such as in een uur 'in an hour'.

Our verb of interest here, draaien 'turn', is classified by van Hout (2004) as a verb that can have a telic or an atelic interpretation, depending on the context. Some other verbs included in this category are koken 'cook, boil', groeien 'grow', and drogen 'dry'. For the latter verb, van Hout (2004:73) provides examples (6) and (7) below, which she describes as follows: With the durative modifier urenlang 'for hours' in (6), the verb drogen 'dry' is atelic and selects hebben; with the frame adverbial in een uur 'in an hour' in (7), the verb is telic and selects zijn.

(6) De was heeft urenlang gedroogd, maar bleef toch vochtig. the laundry has hours.long dried, but remained still damp 'The laundry dried for hours, but still remained damp.'

(7) De was is in een uur gedroogd. the laundry is in an hour dried 'The laundry dried in an hour.' 
Lieber \& Baayen (1997) do not formulate their semantic generalization for Dutch auxiliary choice in terms of telicity. One of their arguments is that a verb such as dalen 'descend' can combine with a durative adverbial, yet still selects zijn as its auxiliary. ${ }^{8}$ They propose a semantic feature 'Inferable Eventual Position or State' or [IEPS]: Verbs that possess this feature select zijn, while those that do not select hebben. For dalen 'descend', for example, Lieber \& Baayen state that it is possible to infer the eventual position of the highest argument of the verb, i.e. 'down' (1997:800). Dalen is therefore analyzed as [+IEPS], which accounts for its uses with $z i j n$, be they telic or atelic.

Note that the examples presented in the Introduction do not differ in terms of telicity or [IEPS]. Both the examples with hebben and with zijn are telic, i.e. they each describe an event that consists of a single 180-degree turn: At the start of the event, the subject is facing away from the contestant, and at the end, the subject is facing towards the contestant. This means that the eventual position of the subject can be inferred: It is contextually well defined. The generalizations in terms of telicity and [IEPS], therefore, cannot account for the examples presented in the Introduction.

\section{An analysis in terms of construal: 'type of act' vs. 'change of state'}

Focussing on manner of motion verbs in combination with prepositional phrases, Beliën $(2008,2012)$ has recently proposed an account of auxiliary choice that relies on the notion of 'construal', i.e. our cognitive ability to conceptualize an event (or object or property) in different ways, cf. e.g. Langacker (1987:138):

The full conceptual or semantic value of a conceived situation is a function of not only its content (to the extent that one can speak of content apart from construal), but also how we structure this content with respect to such matters as attention, selection, figure/ground organization, viewpoint, and level of schematicity.

On the basis of attested examples with verbs such as lopen 'walk', vliegen 'fly', and zwemmen 'swim', Beliën argues that zijn is used when the motion event is construed as a 'change of location', while hebben is used when the event is construed as a 'type of act.' This section argues that this analysis can be extended from manner of motion verbs to directed motion verbs such as draaien 'turn' if the semantic generalization for zijn ('change of location') is replaced by the more abstract notion 'change of state', so as to include other types of change as well.

The notion of construal can also be found, be it implicitly, in Honselaar's (1987) account of Dutch auxiliary choice in terms of 'no change in the subject' (hebben) vs. 'change in the subject' (zijn). Honselaar discusses two directed motion 
verbs, which are therefore of particular interest here: Dalen 'descend' and keren, another Dutch verb of turning, cf. (8)-(10) below (from Honselaar 1987:57-59).

(8) ik ben gedaald

'I have descended'

(9) heb je wel eens (naar 2000 voet) gedaald?

have you ever to 2000 feet descended

'Have you ever descended to 2000 feet?'

(10) toen zijn/hebben we gekeerd

then are/have we turned

'then we turned'

As both dalen and keren, Honselaar argues, imply a certain direction and therefore a change in the subject, they are compatible with zijn, as shown in (8) and (10). However, when the focus is not so much on the change in location, Honselaar suggests that they can also be used with hebben, in all kinds of interpretations. For (9), for example, Honselaar suggests that it could be a question to a pilot in training, i.e. someone who needs to learn how to descend, in which the focus is more on executing the act of descending than on the subject changing location. Honselaar calls this interpretation of hebben uITvoerend, i.e. 'executing. ${ }^{10}$ Keren 'turn', see example (10), is not discussed in detail; Honselaar simply observes that it can be used with both zijn and hebben in all kinds of interpretations.

Using the more specific distinction 'change of state' vs. 'type of act' proposed above, let us now return to the examples from the Introduction, which all clearly involve a change of state: The subject makes a 180-degree turn, i.e. changes orientation. The use of $z i j n$ with these verbs in (4) and (5), therefore, makes sense. Note, however, that an alternative construal is available in the specific context of these shows. The point of a turning event in that context is not so much that the coach (the subject) changes state, but rather that the coach does something, i.e. executes a certain type of act, the act of turning, to convey his or her approval of the contestant. This alternative construal then explains the use of hebben. In fact, the context of these shows seems to lend itself so well to this type of construal of a turning event, that hebben is used even more often than zijn in the set of data considered (see the Introduction: 12 instances of hebben and 2 instances of $z i j n$ ).

\section{Beyond The Voice of Holland: Other verbs of directed motion}

The discussion has so far only involved attested data with draaien 'turn' in the context of The Voice of Holland. The present section widens the scope of the analysis to 
other verbs of motion that imply a certain direction, to show that the use of hebben is not limited to this specific context. In particular, this section applies the analysis to attested examples with keren, as well as to examples with stijgen 'rise'.

Honselaar's (1987) intuition that keren 'turn' can occur with both zijn and hebben, see his (constructed) example (10), can be confirmed by attested data. Googling the strings "zijn we gekeerd" and "hebben we gekeerd" on 22 March 2013 yielded 96 relevant examples with zijn, and 13 examples with hebben. ${ }^{11}$ All these examples describe telic events, usually in some traffic situation or recreational setting, in which the subject referents (in their boats, cars, on their bikes, or while scuba-diving) change their orientation so that they end up facing the other way, cf. (11) with zijn and (12) with hebben.

(11) Omdat we deze afrit misten, zijn we gekeerd bij de volgende afrit ${ }^{12}$ because we this exit missed are we turned at the next exit 'Because we missed this exit, we turned at the next exit.'

(12) Daardoor reden we [...] een afslag voorbij, [...]

that.is.why drove we a turn past dustoen het even rustig was hebben we gekeerd, so when it for.a.little.while quiet was have we turned nog een gevaarlijk kunstje, omdat de weg niet zo breed was quite a dangerous little.trick because the road not so broad was en de greppel behoorlijk diep, maar het lukte ${ }^{13}$ and the ditch quite deep but it succeeded 'That is why we missed a turn, so when it got quiet for a moment, we turned, quite a dangerous trick, because the road was quite narrow and the ditch quite deep, but it worked out.'

The analysis in terms of construal can be seen to apply here as follows. Keren 'turn' clearly implies a change of state, which motivates the abundant use of zijn in the examples that were found. In some cases, however, hebben is used, which can be seen to be motivated by an alternative perspective on the event. In (12), for example, the event of turning requires quite some skill on the part of the driver. The directly preceding context, provided in (13) below, describes the difficult setting in which the car needs to turn: A busy, dusty, and narrow road with potholes and a deep ditch right next to it. The event of turning is, in fact, classified by the speaker as een gevaarlijk kunstje 'a dangerous trick', cf. the third line of example (12): The speaker explicitly focuses on the execution of the act of turning, i.e. the necessary operations the subject needs to carry out to move so that they end up facing the opposite direction. 
(13) [H]et begon met mooi asfalt, maar toen [...] werd het gravel, wat een stof en gaten, en omdat het zo druk was met auto's moest je echt opletten waar je reed, omdat het zo stoffig was.

'It started with lovely tarmac, but it went on to gravel, what a dust and holes, and because it was so busy with cars, you really needed to pay attention to where you were going, because it was so dusty'

A second set of data with directed motion verbs is inspired by example (14), which Sorace (2000: 866) quotes from van Hout (1993:7). This is an atelic example, cf. the durative modifier 3 uur lang 'for three hours', in which the directed motion verb stijgen 'rise, ascend' is combined with both zijn and hebben.

(14) De temperatuur is/heeft 3 uur[ ]lang gestegen, maar is toen weer gezakt the temperature is/has 3 hours risen, but is then again dropped 'The temperature rose for three hours but then dropped again'

The intuitions reflected in (14) can be confirmed by attested data too. An exploratory Google search with "tijdje gestegen" 'risen for [a] while' revealed that atelic stijgen is indeed used with both hebben and zijn. The search yielded 20 hits in total. After the removal of repeated and other irrelevant examples, 10 instances with zijn remained, and 2 instances with hebben; cf. (15) and (16) for examples of each auxiliary verb. ${ }^{14}$

(15) De werkloosheid is vervolgens nog een tijdje gestegen the unemployment is subsequently still a little.while risen tot er weer een moment van stabilisatie aanbrak ${ }^{15}$ until there again a moment of stabilization started 'After that, unemployment rose for yet another while, until there came a moment of stabilization.

(16) Daarna hadden we nog een tijdje gestegen $^{16}$ after.that had we still a little.while ascended 'After that we ascended for a while'

Interestingly enough, the examples with $z i j n$ that were found all involve metaphorical rising. The subjects in the examples with zijn are all concepts that can be quantified, such as stocks, sales figures, and unemployment (figures), like in (15); their quantity is said to have increased for a while (cf. the well-established conceptual metaphor MORE IS UP, Lakoff \& Johnson 1980:15-16). The main message, in other words, is that the subject changed state, so zijn is a natural choice.

The two examples of atelic stijgen that were found with hebben, conversely, both involve physical rising. Example (16) above is about a group of boy scouts who spend their Saturday mountain biking, cf. its preceding context presented 
in (17) below. The use of hebben is motivated here, because the focus can be understood to be more on the strenuous act of biking up a hill than on the subjects' changing state. (16) and (17) together report on a sequence of activities that the boys carried out, i.e. climbing, descending, and then some more climbing, i.e. types of acts which they engaged in for exercise, or fun, or team-building.

(17) Zaterdag gingen [we] mountainbiken. Eerst gingen we stijgen. Voor sommigen was dit erg vermoeiend, maar uiteindelijk zijn we allemaal boven gekomen. Vanzelfsprekend moesten wij ook weer dalen. Dit was ook niet altijd even makkelijk, maar duidelijk veel leuker dan het stijgen.

'Saturday we went mountainbiking. First we climbed. For some, this was exhausting, but ultimately we all made it to the top. Of course then we had to descend. This was not always easy either, but definitely much more fun than climbing.'

The analysis in terms of construal provides a unified account of the attested data presented here: Both telic and atelic verbs of directed motion can combine with hebben and zijn, depending on how the motion event is construed. Hebben is used only occasionally with keren and stijgen, in contexts that seem to particularly favor the type of act construal, such as turning events that require considerable skill or actual physical (as opposed to metaphorical) rising.

Returning once more to Lieber \& Baayen (1997), we can observe that they in fact rely on the notion of construal too, using words such as 'highlighting' and 'backgrounding. They are aware that a verb like dalen can be used with hebben too, even though its status as a [+IEPS] verb would predict zijn. To account for such uses, therefore, Lieber \& Baayen propose a 'productive rule' in Dutch "for changing the value of [aIEPS] into [-aIEPS]" (1997:821), which in my view completely undermines their semantic generalization in terms of [IEPS]. Their idea is that as dalen 'descend' is [+IEPS], hebben 'have' is essentially the 'wrong' auxiliary to be used. This use then "forces a reading onto the verb other than that which the verb normally has" (Lieber \& Baayen 1997: 822): While the use of zijn 'highlights' the eventual position of the subject, this position is 'backgrounded' by the use of hebben, and the 'event as such' is described. In my view, the relevant generalization should not be formulated in terms of [IEPS], but rather in terms of the construal operations that they describe as part of the effects of the productive rule that they propose.

\section{Discussion: Verbs of turning used transitively}

As a final note, let us consider verbs of turning that are used transitively. Draaien 'turn' in (18), for example, takes hun stoel 'their chair(s)' as its direct object, and 
keren 'turn' in (19) de auto 'the car'. Like most transitive verbs, they take hebben as their auxiliary. Theoretically, this could offer an alternative explanation of the examples with hebben discussed in the sections above: They could perhaps be analyzed as transitive verbs with an understood rather than expressed direct object; as transitives, then, they take hebben as their auxiliary.

(18) kandidaten kunnen kiezen uit de coaches die hun stoel gedraaid hebben ${ }^{17}$ candidates can choose from the coaches who their chair turned have 'Candidates can choose from the coaches who have turned their chairs'

(19) Ik waste bang om verder te gaan

I was too afraid to further to go

en dus hebben we de auto gekeerd en zijn terug gereden. ${ }^{18}$

and so have we the car turned and are back driven

'I was too afraid to go any further and so we turned the car and drove back'

There are two reasons, however, for why the examples with hebben discussed in the previous sections are unlikely to involve transitives with unexpressed direct objects. The first is that alongside transitives such as (18) and (19), there are also examples such as (20), in which de auto 'the car' cannot be the unexpressed direct object: Instead, de auto shows up as part of a prepositional phrase headed by met 'with', and still hebben is used.

(20) Na 20 meter hebben we gekeerd met de auto ${ }^{19}$

after 20 meter have we turned with the car

'After 20 meters we turned with our car'

The second reason is that the analysis presented here in terms of 'type of act' vs. 'change of state' applies not just to draaien and keren, but also to verbs that are undoubtedly intransitive, such as the directed motion verbs stijgen 'rise, ascend' and dalen 'descend', and the manner of motion verbs lopen 'walk' and zwemmen 'swim' (cf. Section 4 above, Honselaar 1987; Beliën 2008, 2012). The generalization in terms of construal provides a unified analysis for all of these verbs.

\section{Conclusion}

The paper has evaluated three types of semantic generalization for Dutch auxiliary choice, on the basis of attested data with directed motion verbs. These data were shown to be problematic for accounts of Dutch auxiliary choice in terms of telicity or 'Inferable Eventual Position or State', yet to provide support for analyses that rely on the notion of construal. In particular, the paper has argued that $z i j n$ is 
used when the motion event is construed as a change of state, while hebben is used when it is construed as a type of act.

The data were specific in a number of respects: They featured three different verbs (draaien 'turn', keren 'turn', and stijgen 'rise'), they were the result of entering specific word strings on Google (e.g. voice "coaches * gedraaid" or "tijdje gestegen" 'risen for [a] while'), and many examples were presented within the specific details of their wider contexts. Such data prove to be invaluable for understanding auxiliary choice in Dutch, as they reveal contexts allowing a certain construal - and therefore a certain auxiliary - that may go unnoticed when relying only on constructed examples.

\section{Notes}

1. http://www.thevoiceofholland.com/video/vernice-marques-somebody-that-i-used-to-know/, accessed 22 February 2013.

2. https://twitter.com/kingofatletiek, accessed 22 February 2013.

3. http://forum.fok.nl/topic/1912395/4/25, accessed 22 February 2013.

4. The following strings were Googled: voice "simon * gedraaid", voice "angela * gedraaid", voice "roel * gedraaid", voice "coaches * gedraaid", voice "coach * gedraaid", and voice "niemand * gedraaid". This yielded 36 hits in total, from which repeated and other irrelevant examples were removed, such as passives and telegram-style examples without a perfect auxiliary, leaving the 12 relevant examples with hebben and 2 with zijn mentioned above.

5. http://thevoiceofholland-v.hyves.nl/forum/5553132/-JNq/Voor_welke_coach_zou_jij_ kiezen/, accessed 22 February 2013.

6. http://www.leerwiki.nl/Wat_is_de_opzet_van_de_rondes_van_The_Voice_of_Holland, accessed 22 February 2013.

7. Honselaar (1987:58-59) provides a similar classification of both dalen 'descend' and keren 'turn'. Note that this classification abstracts away from the following difference: The subject of stijgen or dalen necessarily changes location, while the subject of a turning verb need not, cf. Talmy's (2000:35) distinction between 'translational' and 'self-contained' motion - "[i]n translational motion, an object's basic location shifts from one point to another in space. In selfcontained Motion, an object keeps its same basic, or 'average,' location".

8. This is, in fact, also acknowledged by van Hout (2004: 75, fn. 12): "verbs of inherently directed motion such as rise, descend, and fall ... take the typical atelicity[-]indicating temporal modifiers such as for hours - but still select the BE auxiliary". As we shall see in Section 4, however, the situation is even more complex: In atelic contexts, hebben is also found with this type of verb.

9. The distinction is inspired by Haeseryn, Romijn, Geerts, de Rooij \& van den Toorn (1997), who state that $z i j n$ is used with verbs of motion when the idea of a change of location is 
foregrounded, while hebben is used when the focus is on the 'handelingskarakter van de door het werkwoord uitgedrukte werking' (1997:77). Beliën $(2008,2012)$ translates the latter idea as 'type of act' and argues that the type of act need not be conveyed solely by the verb: It can also be conveyed by the combination of a verb and its prepositional phrase.

10. Other interpretations that he observes for uses of gedaald 'descended' with hebben are sAMENVATTEND 'summarizing' (i.e. for iterative cases) and MEEMAKEND 'experiencing'.

11. Googling "zijn we gekeerd" yielded 109 hits, which included 13 repeated examples, which were removed, leaving the 96 relevant examples mentioned above. Googling "hebben we gekeerd" yielded 26 hits, from which repeated as well as transitive examples were removed, leaving the 13 examples mentioned above.

12. http://www.wegenforum.nl/viewtopic.php?f=14\&t=12953, accessed 22 March 2013.

13. http://www.lvwcn-ijslandtour.nl/weblog/?page_id=274, accessed 22 March 2013.

14. The search was done on 22 February 2013. The 'irrelevant' examples included a passive example, two examples without an auxiliary verb, and an example with the modifier na een tijdje 'after a while', which is not a durative adverbial.

15. http://resourcessgd.kb.nl/SGD/19881989/FULLTEXT/SGD_19881989_tekst_0008008.xml, accessed 22 February 2013.

16. http://www.scoutnet.nl/ beelaerts/pivot/entry.php?id=183\&w=rowans, accessed 22 February 2013.

17. http://www.mediacourant.nl/?p=106323, accessed 22 February 2013.

18. http://www.reizentenerife.nl/weekje-tenerife.html, accessed 4 July 2013.

19. http://www.annieschilder.nl/mallorca-2005/donderdag_19_mei.htm, accessed 22 March 2013.

\section{References}

Beliën, Maaike. 2008. Constructions, constraints, and construal: Adpositions in Dutch. Ph.D. dissertation, Vrije Universiteit Amsterdam. Utrecht: LOT.

Beliën, Maaike. 2012. Dutch manner of motion verbs: Disentangling auxiliary choice, telicity and syntactic function. Cognitive Linguistics 23(1). 1-26. DOI: 10.1515/cog-2012-0001

Dowty, David R. 1979. Word meaning and Montague grammar. Dordrecht: Reidel.

DOI: 10.1007/978-94-009-9473-7

Haeseryn, Walter, Kirsten Romijn, Guido Geerts, Jaap de Rooij \& Maarten C. van den Toorn. 1997. Algemene Nederlandse spraakkunst. Groningen: Nijhoff.

Honselaar, Wilhelmus J. J. 1987. Zijn vs. hebben in het samengesteld perfectum. De Nieuwe Taalgids 80(1). 55-68.

van Hout, Angeliek. 1993. On unaccusativity: The relation between argument structure and aspect. Paper presented at the Arbeitsgruppe Strukturelle Grammatik, MPG, Berlin. 
van Hout, Angeliek. 1996. Event semantics of verb frame alternations: A case study of Dutch and its acquisition. Ph.D. dissertation, Katholieke Universiteit Brabant.

van Hout, Angeliek. 2004. Unaccusativity as telicity checking. In Artemis Alexiadou, Elena Anagnostopoulou \& Martin Everaert (eds.), The Unaccusative Puzzle: Explorations of the Syntax-Lexicon Interface, 60-83. Oxford: Oxford University Press.

Lakoff, George \& Mark Johnson. 1980. Metaphors we live by. Chicago, IL: The University of Chicago Press.

Langacker, Ronald W. 1987. Foundations of cognitive grammar. Volume I: Theoretical prerequisites. Stanford, CA: Stanford University Press.

Lieber, Rochelle \& Harald Baayen. 1997. A semantic principle of auxiliary selection. Natural Language and Linguistic Theory 15(4). 789-845. DOI: 10.1023/A:1005897301225

Sorace, Antonella. 2000. Gradients in auxiliary selection with intransitive verbs. Language 76(4). 859-890. DOI: 10.2307/417202

Talmy, Leonard. 2000. Toward a cognitive semantics. Volume II: Typology and process in concept structuring. Cambridge MA: The MIT Press.

Zaenen, Annie. 1993. Unaccusativity in Dutch: Integrating syntax and lexical semantics. In James Pustejovsky (ed.), Semantics and the Lexicon, 129-161. Dordrecht: Kluwer. DOI: 10.1007/978-94-011-1972-6_9

\section{Author's address}

Maaike Beliën

Institute for Languages and Academic Skills

Faculty of Technology, Policy and Management

Delft University of Technology

PO Box 5015

2600 GA Delft, The Netherlands

m.l.belien@tudelft.nl 